\title{
Ortaöğretim Kurumlarında Yönetici ve Öğretmenlerin İş Doyumunun Örgütsel Bağlılığa Etkisi: Şanlıurfa İlinde Bir Çalışma ${ }^{1}$
}

DOI: $10.26466 /$ opus.692816

\author{
Hüseyin Yıldız * - Kasım Kaya ** \\ * Yüksek Lisans Öğrencisi, Harran Üniversitesi, İ.̇̇.B.F, Şanlıurfa /Türkiye \\ E-Posta: yh.huseyin@gmail.com \\ ORCID: 0000-0003-1994-6368 \\ ** Dr. Öğr. Üyesi, Harran Üniversitesi, İktisadi ve İdari Bilimler Fakültesi, Şanlıurfa /Türkiye \\ E-Posta: kkaya@harran.edu.tr \\ ORCID: $\underline{0000-0001-8942-4659}$
}

Öz

Bu çalışma Milli Eğitim Bakanlı̆̆ına bağlı ortaöğretim kurumlarında çalışan yönetici ve öğretmenlerin iş doyumunun örgütsel bağllilğa etkisinin olup olmadığının tespitine yöneliktir. Bu çalışma 2018-2019 eğitim öğretim yılında Şanlıurfa ilinde ortaöğretim kurumlarında görev yapan 6182 yönetici ve öğretmenler arasinda Şanlıurfa merkez Haliliye, Eyyübiye ve Karaköprü ilçelerinde rastgele seçim ile uygulanmıştır. Çalışma amacı doğrultusunda anket soruları hazırlanmış, 401 öğretmen ve yöneticiye gönüllük esasına göre uygulanmıştır. Veriler SPSS analiz programı ile analiz edilmiştir. Verilerin normal dağ̆llımını belirlemek için Shapiro-Wilk Testi yapılmıştır. Çalışmada faktör analizi, frekans analizi ve demografik faktörler bağlamında farklılikları araştırmaya yönelik Mann Whitney U Testi ve Kruskal Wallis-H Testine yer verilmiştir. Ayrıca iş doyumu düzeyi ile örgütsel bağhllık düzeyi arasındaki ilişkiyi belirlemek için Spearman Korelasyon Testi kullanılmıştır. Ölçeklerin güvenilirliğini ölçmek için ise Cronbach's Alpha değerleri hesaplanmıştır. Yapılan analiz sonucunda ortaöğretim kurumlarında görev yapan öğretmenlerin ve yöneticilerin iş doyum düzeyleri ve örgütsel bağlllık düzeyleri arasında anlaml ve pozitif bir ilişki bulunmuştur. Ayrıca her iki değişkenin demografik faktörler bă̆lamında farklllık gösterip göstermeyeceğini belirlemek amacıyla yapılan analizler neticesinde kişisel özellikler bağlamında iş doyumu düzeyinde ve örgütsel bağlllık düzeylerinde anlaml farklılıklar tespit edilmiştir.

Anahtar Kelimeler: iş doyumu, örgütsel bağlllık, demografik faktörler

\footnotetext{
${ }^{1}$ Bu çalışma, Dr. Öğr. Üyesi Kasım KAYA danışmanlığında, Harran Üniversitesi Sosyal Bilimler Enstitüsü bünyesinde yürütülen ve Hüseyin YILDIZ tarafından hazırlanan "Ortaöğretim Kurumlarında Yönetici ve Öğretmenlerin Iş Doyumunun Örgütsel Bağlıığa Etkisi: Şanlıurfa Ilinde Bir Çalışma” başılılı yüksek lisans tezinden üretilmiştir.
} 


\title{
The Effect of Job Satisfaction of Managers and Teachers on Organizational Commitment in Secondary Education Institutions: A Study in Şanlıurfa Province
}

\begin{abstract}
This study is intended to determine whether the job satisfaction of administrators and teachers working in secondary education institutions affiliated to the Ministry of National Education has an effect on their organizational commitment. The study was carried out on 6182 teachers and managers working at high schools in Şanliurfa during the 2018-2019 educational season, randomly selected from the provinces Haliliye, Eyyübiye and Karaköprü. Within the concept of the study, a questionnaire was prepared and carried out on 401 volunteers, yielding data analyzed via SPSS. In order to determine the normal distribution, Shapiro Wilk test was employed. To investigate the distinctions based on factor analysis, frequency analysis and demographic factors, Mann Whitney $U$ and Kruskal Wallis-H tests were carried out, including Spearman Correlation Test employed to determine the correlation between the occupational satisfaction and organizational commitment. Cronbach's Alpha values were also calculated to evaluate the reliability of the scales. As a result of the analysis, there appeared a significant and positive correlation between the occupational satisfaction and organizational commitment of the teachers and managers working at the governmental high schools.
\end{abstract}

Keywords: job satisfaction, organizational commitment, demographic factors 


\section{Giriş}

Örgütsel bağlılık, kişinin iş yerine karşı hissettiği tepkileri ve tutumlarıdır. İş doyumu ise çalışanın yaptığ işten elde ettiği memnuniyet, işinden duyduğu mutluluktur. İş görenin çalıştığı işten aldığı haz ve doyum onun örgüte olan bağını da etkilemektedir. Sonuç olarak çalışanın işteki başarı ve verimini etkilemektedir (Şenergüç, 2009, s.3).

Genel anlamda iş doyumu, iş görenlerin işinden memnun olma düzeyi şeklinde değerlendirilebilir. İş memnuniyeti, kişinin yaptığ 1 çalışmaya gösterdiği duygusal bir tepkidir. Çalışmanın karşılığında elde ettiği geliri, iş ortamında birlikte vakit geçirdiği çalışma arkadaşlarından aldığı memnuniyetlik düzeyi ve çalışması sonucunda ortaya koyduğu ürüne karşı oluşturduğu mutluluk duygusu iş doyumunun ifadesidir. İş doyumu, psikososyal bir tepki olduğundan soyut ve ölçülmesi zor olan bir kavramdır (Yılmaz ve Ceylan, 2011, s.281).

İş memnuniyetini yaş, cinsiyet, eğitim seviyesi, işteki statü, kişilik gibi bireye ait olan kişisel etkenlerin yanında yapılan çalışmanın niteliği, ücret, iş arkadaşları, iletişim, güvenlik gibi işletmeye ait olan etkenler çoğunlukla belirleyici olmaktadır ( Mavuş, 2014, s.9).

Örgütüne bağlılık hisseden çalışan; işletmenin amaçlarını ve değerlerini benimser, içten kabullenir ve iş gördüğü işletmede yıllarca istikrarlı bir şekilde devam etme arzusu içinde olur. İşletmesinin çıkarını gözeterek çalışır ve örgütsel bağlllı̆̆ı zayıf olan çalışanlara örnek olur. İşletmenin hedef ve stratejilerine paralel olarak daha çok çaba gösterir (Tok, 2007, s.21).

Örgütsel bağlllık kavramı, iş doyumu kavramından daha geniş bir olgudur, hatta iş doyumunu da içine alan daha geniş bir kavramdır. İş doyumu kişinin işinden aldığı haz iken, örgütsel bağlılık örgütün bütününe karşı beslenen algıdır. İş doyumu çalışanın gün içindeki psikolojik durumundan hemen etkilenirken, örgütsel bağlılık duygulardan çok sonuçları olan davranışlardan etkilendiğinden iş doyumu kadar hassas değildir (Tok, 2007, s.24).

Mowday, Porter ve Steers'e göre iş doyumu ve örgüte bağlllık, örgütün işleyiş şeklini ve iş ortamını etkileyen duygusal davranışları üzerinde belirleyici rol oynamaktadır. Örgütsel bağlılık ile işletmenin ortaya koyduğu hedef ve değerlerine bağlılığı öne çıkarırken, is doyumu ile çalışan bireylerin işleri için ortaya koydukları edimle açıklanmaktadır. Örgütsel bağlılık uzun zaman 
içerisinde gerçekleşen edimlerden etkilenirken, is doyumu ise daha ani gelişen kısa süreli günlük olaylardan etkilenmektedir (Luthans, 1992).

\section{Bu Konuda Yapılan Çalışmalar}

Yıldız (2013), araştırmasında işletmede çalışan ast ve üst kademedeki bireylerin örgütlerinden beklentileri ve bu beklentilerin yerine getirilme seviyesi şeklinde değerlendirebileceğimiz iş doyum düzeyi ile çalışanların adalet algılarının birbiriyle bağıntıyı araştırmıştır. Buna göre iş doyumu algısı artıkça örgütsel adalet algıların düzeyi de doğru orantılı olarak yükselmektedir (Yıldız, 2013). Karşılaştırmalı olarak kamu ile özel sektörü arasında iş doyumunun örgütsel bağlılığa etkisi araştırılmıştır. Çalışma neticesinde kamu kurumunda görev yapan çalışanların özel sektörde çalışan personele göre örgütsel bağlllık düzeyleri daha fazla olduğu görülmüş̧ür (Karaca, 2001). Kişiye ait faktörlerden yaş ile duygusal ve normatif bağlllık arasında olumlu yönde, örgüte çalışmayı sürdürme arzusu arasında olumsuz yönde bir ilişki görüldüğü; eğitim düzeyi ile duygusal bağlılık ve işletme çalışmayı sürdürme arzusu arasında anlamlı bir ilişkinin görülmediği; eğitim düzeyi ile normatif bağlılık arasında olumsuz yönde bir ilişki görüldüğü, statü ile duygusal bağlılık arasında anlamlı bir ilişkinin var olmadığı, ancak statü ile örgütte çalışmayı sürdürme arzusu ile normatif bağlllık arasında olumuz bir ilişkinin görüldüğü; kıdem ile duygusal ve normatif bağlllık arasında olumlu yönde bir ilişki bulunurken, örgütte çalışmayı sürdürme arzusu ile kıdem arasında anlamlı bir ilişkinin görülmediği saptanmıştır (Yıldırım, 2002). Akınaltuğ (2003), araştırmasında, iş doyumunun örgütsel bağlllıkla doğru orantılı bir şekilde şekilde değiştiğini; iş doyumu yükseldikçe örgütsel bağlılığın da yükseldiğini göstermiştir. Ergü (1998), çalışmasında, iş doyumu konusunu araştırmış ve bakanlık müfettişleri ile ilköğretim müfettişlerinin iş memnuniyeti seviyelerini değerlendirilerek ortaya koyduğu veriler kullanılarak karşılaştırma çalışmıştır. İş doyumu yüksek olan müfettişlerin örgütsel bağllıkları da yüksek olduğu görülmüştür Motivasyon ile doyum arasındaki ilişkiyi incelemek için üniversite öğrencileriyle yapılan çalışmada 102 kadın ve 24 erkek denek kullanılmıştır. Öğrencilerin bireysel etkilerinden dolayı farklıların oluştuğu belirtilmektedir. Bu farklılıklara rağmen motivasyon ile doyum arasında olumlu ilişki görülmüştür (Donohue and Wong, 1997). Meksika'da çalışanların iş doyumu ve örgütsel bağlılık düzeyleri üzerine yapılan inceleme; 
çalışanların motivasyonu, bağlllık düzeyleri, iş doyumu ve örgüt prestiji ele alınmıştır. Otomotiv alanında çalışan personeller arasında 42 aylık süre içinde elde edilen çalışmaya göre; işin sağladığ statü imkanları, iş arkadaşlarıyla ilişkileri örgütün mali ve sosyal durumu, denetimler, müfettiş tutum ve davranışları iş doyumunu etkilediği saptanmıştır. Çalışmanın sonucuna göre iş doyumu ve örgütsel bağlılık arasında olumlu yönde ilişkinin olduğu değerlendirilmiştir (Peterson, Puia, Suess, 2003).

\section{Yöntem}

\section{Araştırmanın Amacı ve Kapsamı}

Bu Araştırma Milli Eğitim Bakanlığı'na bağlı ortaöğretim kurumlarında çalışan yönetici ve öğretmenlerin iş doyumlarının örgütsel bağlllıklarını etkileme düzeylerini belirlemeye yöneliktir. Ayrıca bu düzeyler arasında demografik faktörler açısından anlamlı farklılıklar olup olmadığı bir diğer araştırma konusudur.

Bu araştırmanın amacı, MEB'e bağlı ortaöğretim kurumlarında çalışan öğretmenlerin ve yöneticilerin iş doyumları ile örgütsel bağlılık düzeyleri arasındaki ilişkiyi tespit etmektir. Araştırmanın bir diğer amacı da, iş doyumu düzeyi ve örgütsel bağll1ık düzeylerinde demografik özelliklerine göre anlamlı bir farklılık olup olmadığını saptamaktır.

\section{Araştırmanın Sinırlılıkları}

Araştırma iş doyumu ve örgütsel bağlllık ilişkisinin daha görünür olduğu düşünülen eğitim sektöründe yapılmıştır. Zaman ve bütçe darlığı açısından araştırma Şanlıurfa ilinde gönüllü katılımlı olarak yapılmıştır.

\section{Varsayimlar}

Katılımcıların iş doyum düzeyleri ile örgütsel bağlllık düzeyleri arasında bir ilişki olduğu varsayılmıştır.

Katılımcıların iş koşulları sırasında iş doyumunu etkileyen tüm değişkenleri tecrübe ettiği varsayılmıştır.

Şanlıurfa İlinde çalışan öğretmen ve yöneticilerin demografik özeliklerinin farklı olduğu varsayılmıştır. 


\section{Evren ve Örneklem}

Araştırmanın ana kütlesini Şanlıurfa ilindeki ortaöğretim kurumlarında çallşan öğretmen ve yöneticiler oluşturmaktadır. Şanlıurfa ilinin seçilmesinin nedeni bu ilde çalışan öğretmen ve yöneticilerin demografik özellikleri bakımindan farklı olduklarının düşünülmesidir. Araştırmanın örneklemi; tesadüfi olmayan örnekleme yöntemlerinden kolayda örneklemesidir. Çalışmaya konu olan evren 6182 kişiden oluşmaktadır. Örneklem sayısı \%95 güvenirlilik ve \% 5 hata payı ile 357 olarak belirlenmiştir (Yazıcıoğlu ve Erdoğan, 2004, s.50). Anket 401 öğretmen ve yönetici tarafından doldurulmuştur.

\section{Veri Toplama Teknikleri}

Araştırma için gerekli olan veriler, birincil veri toplama yöntemlerinden anket metodu uygulanarak toplanmıştır. Verilerin toplanmasında yüz yüze anket metodu kullanılmıştır. Anketörün cevaplayıcıyla iletişime geçtiği yüz yüze anket metodu en güvenilir veri toplama yöntemleri arasında yer almaktadır (Gegez, 2010, s.83).

Anket formu, üç bölümden oluşmaktadır. İlk bölümde, katılımcıların cinsiyeti, yaşı, medeni durumu, eğitim düzeyi, görevi ve kıdemi olmak üzere altı demografik soruya yer verilmiştir. İkinci bölümde, Çetinkanat (2000) tarafından geliştirilen 32 maddeden oluşan iş doyumu ölçeği yer almaktadır. Üçüncü bölümde ise, Meyer ve Allen (1997) tarafından geliştirilen 24 maddeden oluşan örgütsel bağlllık ölçeği yer almaktadır.

Araştırma amacı doğrultusunda oluşturulan anket 401 kişiye uygulanmiştır. Anketler doğruluk, tutarlılık ve dürüstlük açısından elendikten sonra 401 kişi üzerinden değerlendirilmiştir. İş doyumu ve örgütsel bağlllık ile ilgili sorular 5'li likert ile sorulmuştur. (1) Kesinlikle Katılmıyorum, (2)Katılmıyorum, (3) Ne Katılıyorum Ne Katılmıyorum, (4) Katılıyorum ve (5)Kesinlikle Katılıyorum, şeklinde değerlendirmeye alınmıştır.

\section{Araştırmada Kullanılan Yöntemler}

Araştırma ile toplanan veriler, SPSS programı kullanılarak analiz edilmiştir. Verilerin normal dağılımını belirlemek için Shapiro-Wilk Testi yapılmıştır. Çalışmada faktör analizi, frekans analizi ve demografik faktörler bağlamında farklılıkları araştırmaya yönelik Mann Whitney U Testi ve Kruskal Wallis-H Testine yer verilmiştir. Ayrıca iş doyumu düzeyi ile örgütsel bağlılık düzeyi 
arasındaki ilişkiyi belirlemek için Spearman Korelasyon Testi kullanılmıştır. Ölçeklerin güvenilirliğini ölçmek için ise Cronbach's Alpha değerleri hesaplanmıştır.

\section{Bulgular}

\section{Normal Dă̆ılım ve Güvenirlilik Analizi}

Yapılan normallik testi analizi sonuçları değerlendirildiğinde grupların "Shapiro-Wilk" testinin "Sig (anlamlılık)" değerleri 0.05' den küçük olduğu için tüm gruplar için \%95 güvenle veriler normal dağllımlı değildir" sonucuna ulaşılmıştır.

Cronbach Alfa Katsayısının değerlendirilmesinde uyulan değerlendirme kriterleri genelde şu şekildedir (Altunışık, Coşkun, Bayraktaroğlu ve Yıldırim, 2005, s.115).

- Alfa katsayısı 0,40’ tan küçük: Ölçek güvenilir değil,

- Alfa katsayısı 0,41-0,60 arası: Ölçek düşük düzeyde güvenilir,

- Alfa katsayısı 0,61-0,80 arası: Ölçek oldukça güvenilir,

- Alfa katsayısı 0,81-1,00 arası: Ölçek yüksek derecede güvenilirdir.

Araştırmada kullanılan iki ölçeğe yönelik güvenilirlik analizine göre, iş doyumu ölçeğinin Cronbach's Alfa değeri 0,891 olduğu ve örgütsel bağlllık ölçeğinin Cronbach's Alfa değeri 0,781 olarak tespit edilmiştir. İş doyumu ölçeğinin yüksek derecede güvenilir olduğu ve örgütsel bağlılık ölçeğinin oldukça güvenilir olduğu tespit edilmiştir.

\section{Faktör Analizi}

Faktör analizi, veriler arasındaki ilişkilere dayanarak, bu verilerin daha anlamlı ve özet biçimde sunulmasını sağlayan bir analiz türüdür. Faktör analizinde amaç, çok miktardaki değişken sayısının değişken seti içindeki karşılıklı ilişkiyi araştırarak azaltmaktır. Faktör analizi ile ankette ölçülen farklı faktörleri belirleme ve her faktördeki her değişken için bir faktör yükü elde etme imkânı verir (Proctor, 2003, s.292).

Araştırmada iki ayrı ölçeğe faktör analizi uygulanmıştır. Öncelikle iş doyumuna yönelik değişkenlerle ilgili 32 maddeye ve örgütsel bağlllığa yönelik değişkenlerle ilgili 24 maddeye ayrı ayrı faktör analizi uygulanmıştır. 
Iş̧ Doyumunu Ölçmeye Yönelik Değişkenlerin Faktör Analizi: KMO (örnekleme yeterliliği istatistiği) ve Bartlett's Test of Sphericity (Bartlett küresellik testi) değişkenler arasında yeterli oranda ilişki olup olmadığını gösterir. Eğer Bartlett testinin p değeri 0,05 anlamlılık derecesinden düşük ise değişkenler arasında faktör analizi yapmaya yeterli düzeyde ilişki vardır. KMO örnekleme yeterliliğinin kabul edilebilir en alt sınırı 0,50'dir (Sipahi, Yurtkolu, ve Çinko, 2006, s.79). Tablo 3'te de görüldüğü üzere, verilerin faktör analizine uygun olup olmadığını belirleyen KMO değeri $(0,847)$, faktör analizi yapılabilmesi için uygun bir değerdir. Yine aynı nedenle yapılan Bartlett testi Significance $=0,000$ olduğundan ve $\mathrm{p}<0.05$ olduğundan verilerin faktör analizi için uygun olduğuna karar verilmiştir. Yapılan faktör analizinde, dikey döndürme yöntemlerinden Varimax yöntemi kullanılmıştır. Analiz sonucunda, kullanılan ölçekteki ifadelerin altı ayrı boyuta dağıtıldığı görülmüştür. Faktör analizi sonucuna göre elde edilen açıklayıcılık oranı \%65,850'dir.

Örgütsel Bağhlı̆̆ı Ölçmeye Yönelik Değişkenlerin Faktör Analizi: Faktör analizine uygun olup olmadığını belirleyen KMO değeri $(0,749)$, faktör analizi yapılabilmesi için uygun bir değerdir. Yine aynı nedenle yapılan Bartlett testi Significance $=0,000$ olduğundan ve $p<0.05$ olduğundan verilerin faktör analizi için uygun olduğuna karar verilmiştir. Yapılan faktör analizinde, dikey döndürme yöntemlerinden Varimax yöntemi kullanılmıştır. Analiz sonucunda, kullanılan ölçekteki ifadelerin üç ayrı boyuta dağıtıldığı görülmüştür. Faktör analizi sonucuna göre elde edilen açıklayıcılık oranı \%72,415.

\section{Demografik Faktörlerin Analizi}

Araştırmaya katılan öğretmen ve yöneticilerin cinsiyetlerine göre dağılımına bakıldığında, katılımcıların 218'inin (\%54,4) kadın ve 183'ünün (\%45,6) erkek bireylerden oluşmaktadır. Araştırmaya katılan öğretmen ve yöneticilerin medeni durumlarına göre dağılımına bakıldığında, katılımcıların 129'unun $(\% 32,2)$ evli ve 272 'sinin $(\% 67,8)$ bekar bireylerden oluşmaktadır. Bu oran, ankette her iki cinsiyetten olan katılımcıların düşüncelerini yansıtması için uygundur. Katılımcıların 43'ünün (\%10,7) 20-25 yaş aralığında, 152'sinin $(\% 37,9)$ 26-31 yaş aralığında, 96'sının (\%23,9) 32-37 yaş aralığında, 76'sının $(\% 19,0)$ 38-43 yaş aralığında ve 34'ünün $(\% 8,5) 44$ ve üzeri yaş aralığında olduğu görülmektedir. Araştırmaya katılan öğretmen ve yöneticilerin eğitim 
düzeylerine göre dağılımına bakıldığında, katılımcların 1'inin $(\% 0,2)$ ön lisans eğitim düzeyinde, 328'inin $(\% 89,3)$ lisans eğitim düzeyinde, $40^{\prime} 1 \mathrm{n}$ ın $(\% 10,0)$ yüksek lisans eğitim düzeyinde ve 2 'sinin $(\% 0,5)$ doktora eğitim düzeyinde olduğu görülmektedir. Katılımcların görev dağılımına bakıld1ğında, katılımclların 382'sinin (\%95,3) öğretmen, 11'inin (\%2,7) müdür yardımcısı ve 8 'inin $(\% 2,0)$ müdür olduğu görülmektedir. Araştırmaya katılan öğretmen ve yöneticilerin kıdemlerine göre dağılımına bakıldığında, katılımcıların 150'sinin (\%37,4) 1-5 yıl aralığında, 96'sının (\%23,9) 6-10 yıl aralığında, 70 'inin $(\% 17,5)$ 11-15 yıl aralığında, 61'inin $(\% 15,2)$ 16-20 yıl aralığında ve 24 ünün (\%6,0) 20 yıl ve üzeri kıdemde oldukları görülmektedir.

\section{Hipotezlerin Test Edilmesi}

İş doyumu düzeyi ile örgütsel bağlllık düzeyi arasındaki ilişkiyi belirlemeye yönelik olarak nonparametrik test olan Spearman Korelasyon Testi analizi yapılmıştır. Bu amaçla şu hipotez kurulmuştur.

- $\quad H_{1}$ : Öğretmen ve yöneticilerin iş doyum düzeyleri ile örgütsel bağlılık düzeyleri arasında anlamlı bir ilişki vardır.

Tablo 1. İş Doyumu Düzeyi ile Örgütsel Bağlılık Düzeyi Arasındaki İlişkiyi Belirlemeye Yönelik Sperman Korelasyon Analizi Sonuçlan

\begin{tabular}{|c|c|c|c|c|}
\hline Spearman's rho & & & İş Doyumu & Örgütsel Bağlılık \\
\hline \multirow[t]{6}{*}{ Spearman's rho } & \multirow[t]{3}{*}{ İş Doyumu } & Korelasyon Katsayı & 1,000 &, $270^{* *}$ \\
\hline & & Sig. (2-tailed) & . & 000 \\
\hline & & $\overline{\mathrm{N}}$ & 401 & 401 \\
\hline & \multirow[t]{3}{*}{ Örgütsel Bağlılık } & Korelasyon Katsay1 &, $270^{* *}$ & 1,000 \\
\hline & & Sig. (2-tailed) &, 000 & . \\
\hline & & $\mathrm{N}$ & 401 & 401 \\
\hline
\end{tabular}

**. Korelasyon 0.01 düzeyinde önemlidir (2 kuyruklu).

Katılımcıların iş doyumları ile örgütsel bağlılık düzeyleri arasındaki ilişkiyi belirlemeye yönelik olarak yapılan Spearman korelasyon analizi sonucunda elde edilen sig. (p) değeri ,000'dır. $p=, 000$ değeri ,05 değerinden küçük olduğu için bu iki değişken arasında anlamlı bir ilişki olduğu sonucu elde edilmiştir. Korelasyon katsayısı yani $\mathrm{r}$ değeri 0,00-0,25 arasında ise çok zayıf, 0,26-0,49 arasinda ise zayıf, 0,50-0,69 arasinda ise orta, 0,70-0,89 arasinda ise güçlü ve 0,90-1,00 arasında ise çok güçlü bir ilişki olduğu yorumu yapılabilir (Arslan, 2018, s.53). İş doyumu düzeyi ve örgütsel bağlllık düzeyi arasındaki 
korelasyon kat sayısı değeri $\mathrm{r}=, 270$ olduğundan dolayı aralarında pozitif ve zayıf bir ilişki olduğu sonucuna varılmıştır. Yani iş doyumu düzeyi arttıkça örgütsel bağllıık düzeyi de pozitif yönde artmaktadır (Tablo 1). $\mathrm{H}_{1}$ hipotezi desteklendi.

Katılımcların demografik özelliklerine göre iş doyum düzeylerinin istatistiksel açıdan değerlendirmesini yapmak amacıyla şu hipotezler kurulmuştur.

- $\quad \mathbf{H}_{2}$ : Öğretmen ve yöneticilerin demografik faktörleri açısından iş doyumu düzeylerinde anlamlı bir farklılık vardır.

- $\quad H_{2 a}$ : Öğretmen ve yöneticilerin cinsiyetleri açısından iş doyumu düzeylerinde anlamlı bir farklılık vardır.

- $\quad \mathbf{H}_{2 b}$ : Öğretmen ve yöneticilerin medeni durumları açısından iş doyumu düzeylerinde anlamlı bir farklılık vardır.

- $\quad \mathbf{H}_{2}$ : Öğretmen ve yöneticilerin yaşları açısından iş doyumu düzeylerinde anlamlı bir farklılık vardır.

- $\quad H_{22}$ : Öğretmen ve yöneticilerin eğitim düzeyleri açısından iş doyumu düzeylerinde anlamlı bir farklılık vardır.

- Hze: Öğretmen ve yöneticilerin görevleri açısından iş doyumu düzeylerinde anlamlı bir farklılık vardır.

- $\quad \mathbf{H}_{2 f:}$ Öğretmen ve yöneticilerin kıdemleri açısından iş doyumu düzeylerinde anlamlı bir farklılık vardır.

Tablo 2. Öğretmenlerin ve Yöneticilerin Cinsiyetleri Açısından İs Doyumu Düzeylerine Yönelik Mann Whitney U Testi Sonuçlarn

\begin{tabular}{|c|c|c|c|c|}
\hline İş Doyumu & $\mathrm{N}$ & Mean & $\mathrm{Z}$ & Sig. \\
\hline Kadın & 218 & 3,4201 & \multirow[b]{2}{*}{$-1,477$} & \multirow{2}{*}{ 140 } \\
\hline Erkek & 183 & 3,5374 & & \\
\hline Yönetim Biçimleri & $\mathrm{N}$ & Mean & $Z$ & Sig. \\
\hline Kadın & 218 & 3,4725 & \multirow{2}{*}{$-2,148$} & \multirow{2}{*}{,032 } \\
\hline Erkek & 183 & 3,6481 & & \\
\hline Çalışma Olanakları & $\mathrm{N}$ & Mean & $Z$ & Sig. \\
\hline Kadın & 218 & 2,6651 & \multirow{2}{*}{$-2,890$} & \multirow{2}{*}{,004 } \\
\hline Erkek & 183 & 2,9381 & & \\
\hline Gelişme ve Yükselme Ol. & $\mathrm{N}$ & Mean & $\mathrm{Z}$ & Sig. \\
\hline Kadın & 218 & 3,8450 & \multirow[b]{2}{*}{$-1,052$} & \multirow[b]{2}{*}{,293 } \\
\hline Erkek & 183 & 3,8109 & & \\
\hline İş Arkadaşları & $\mathrm{N}$ & Mean & $Z$ & Sig. \\
\hline Kadın & 218 & 3,7634 & \multirow{2}{*}{-116 } & \multirow{2}{*}{907} \\
\hline Erkek & 183 & 3,7736 & & \\
\hline Fiziksel Ortam & $\mathrm{N}$ & Mean & $Z$ & Sig. \\
\hline
\end{tabular}




\begin{tabular}{lllll}
\hline Kadın & 218 & 3,2913 & $-1,762$ & \multirow{2}{*}{078} \\
\hline Erkek & 183 & 3,4918 & Z & Sig. \\
\hline Ücret ve Personel & $\mathrm{N}$ & Mean & Z & \multirow{2}{*}{, 749} \\
\hline Kadın & 218 & 3,2890 &,- 321 & \\
\hline Erkek & 183 & 3,3169 & & \\
\hline
\end{tabular}

Katılımcların cinsiyetlerine göre iş doyumu düzeylerinde bir farklılık olup olmadığını ölçmek için yapılan Mann Whitney U Testi analiz sonucunda ulaşılan değer $p=, 140>, 05$ olmasından dolayı öğretmenlerin ve yöneticilerin cinsiyetleri açısından iş doyumu düzeylerinde anlamlı bir farklılık olmadığı sonucuna ulaşılmıştır. Öğretmenlerin ve yöneticilerin cinsiyetlerine göre iş doyumu ölçeğinin alt faktörlerinde de farklılık olup olmadığını belirlemek için Mann Whitney U Testi yapılmıştır. Yapılan analiz sonucunda "Yönetim Biçimleri" ve "Çalışma Olanakları" faktörlerinde elde edilen p değerleri sırası ile ,032 ve ,004 <,05 olduğundan bu iki faktör düzeyinde katılımc1ların cinsiyetleri açısından anlamlı bir farklılık olduğu tespit edilmiştir. Her iki alt faktörde de erkeklerin kadınlardan daha yüksek doyum düzeyinde olduğu sonucuna ulaşılmıştır (Tablo 2). H2a hipotezi desteklendi.

Katılımciların medeni durumlarına göre iş doyumu düzeylerinde bir farklılık olup olmadığını ölçmek için yapılan Mann Whitney U Testi analiz sonucunda ulaşılan değer $p=, 176>, 05$ olmasından dolayı öğretmenlerin ve yöneticilerin medeni durumları açısından iş doyumu düzeylerinde anlamlı bir farklılık olmadığı sonucuna ulaşılmıştır. Öğretmenlerin ve yöneticilerin medeni durumlarına göre iş doyumu ölçeğinin alt faktörlerinde de farklılık olup olmadığını belirlemek için Mann Whitney U Testi yapılmıştır. Yapılan analiz sonucunda "Çalışma Olanakları", "Fiziksel Ortam" ve "Ücret ve Personel" faktörlerinde elde edilen p değerleri sırası ile ,008 , ,040 vw, 009<,05 olduğundan bu üç faktör düzeyinde katılımcıların medeni durumları açısından anlamlı bir farklılık olduğu tespit edilmiştir. Her üç alt faktörde de bekarların evlilerden daha yüksek doyum düzeyinde olduğu sonucuna ulaşılmıştır (Tablo 3). H2b hipotezi desteklendi. 
Tablo 3. Öğretmenlerin ve Yöneticilerin Medeni Durumlarn Açısından İş Doyumu Düzeylerine Yönelik Mann Whitney U Testi Sonuçlan

\begin{tabular}{|c|c|c|c|c|}
\hline İş Doyumu & $\mathbf{N}$ & Mean & $\mathrm{Z}$ & Sig. \\
\hline Evli & 129 & 3,3740 & \multirow{2}{*}{$-1,352$} & \multirow{2}{*}{ 176 } \\
\hline Bekar & 272 & 3,5209 & & \\
\hline Yönetim Biçimleri & $\mathbf{N}$ & Mean & $\mathrm{Z}$ & Sig. \\
\hline Evli & 129 & 3,4566 & \multirow{2}{*}{,- 855} & \multirow{2}{*}{,392 } \\
\hline Bekar & 272 & 3,5982 & & \\
\hline Çalışma Olanakları & $\mathbf{N}$ & Mean & $\mathrm{Z}$ & Sig. \\
\hline Evli & 129 & 2,5930 & \multirow{2}{*}{$-2,664$} & \multirow{2}{*}{,008 } \\
\hline Bekar & 272 & 2,8830 & & \\
\hline Gelişme ve Yükselme Olanakları & $\mathbf{N}$ & Mean & $\mathrm{Z}$ & Sig. \\
\hline Evli & 129 & 3,8062 & \multirow{2}{*}{-392} & \multirow{2}{*}{ 695 } \\
\hline Bekar & 272 & 3,8404 & & \\
\hline İş Arkadaşları & $\mathbf{N}$ & Mean & $\mathrm{Z}$ & Sig. \\
\hline Evli & 129 & 3,7409 & \multirow{2}{*}{-182} & \multirow{2}{*}{,856 } \\
\hline Bekar & 272 & 3,7810 & & \\
\hline Fiziksel Ortam & $\mathbf{N}$ & Mean & $\mathrm{Z}$ & Sig. \\
\hline Evli & 129 & 3,1977 & \multirow{2}{*}{$-2,055$} & \multirow{2}{*}{,040 } \\
\hline Bekar & 272 & 3,4706 & & \\
\hline Ücret ve Personel & $\mathbf{N}$ & Mean & $\mathrm{Z}$ & Sig. \\
\hline Evli & 129 & 3,1163 & \multirow{2}{*}{$-2,624$} & \multirow{2}{*}{,009 } \\
\hline Bekar & 272 & 3,3897 & & \\
\hline
\end{tabular}

Katılımcların yaş durumlarına göre iş doyumu düzeylerinde bir farklılık olup olmadığını ölçmek için yapılan Kruskal Wallis H Testi analizi sonucunda iş doyumu düzeyinde ulaşılan değer $\mathrm{p}=0,000<0,05$ olmasından dolay 1 öğretmenlerin ve yöneticilerin yaşları açısından iş doyum düzeylerinde anlamlı bir farklılık olduğu sonucuna ulaşılmıştır(Tablo 4).

Tablo 4. Öğretmenlerin ve Yöneticilerin Yaşlan Açısından İş Doyumu Düzeylerine Yönelik Kruskal Wallis-H Testi Sonuçlar

\begin{tabular}{llllllll}
\hline & \multirow{2}{*}{ İş Doyumu } & $\begin{array}{l}\text { Yönetim } \\
\text { Biçimleri }\end{array}$ & $\begin{array}{l}\text { Çalışma } \\
\text { Olanakları }\end{array}$ & $\begin{array}{l}\text { Gelişme } \\
\text { ve Yükselme }\end{array}$ & İş Ark. & $\begin{array}{l}\text { Fiziksel } \\
\text { Ortam }\end{array}$ & $\begin{array}{l}\text { Ücret ve } \\
\text { Personel }\end{array}$ \\
\hline Ki-kare & 35,193 & 21,951 & 32,235 & 8,434 & 13,653 & 29,055 & 25,880 \\
\hline Df & 4 & 4 & 4 & 4 & 4 & 4 & 4 \\
\hline Asymp. Sig., 000 &, 000 &, 000 &, 077 &, 008 &, 000 &, 000 \\
\hline
\end{tabular}

Analiz sonuçlarına göre iş doyumunda 44 ve üzeri yaş aralığında olan katılımcların diğer yaş gruplarına göre iş doyumu düzeylerinin daha yüksek olduğu belirlenmiştir. Alt faktörlerin tümüne yapılan analiz sonucunda "yönetim biçimleri", "çalışma koşulları", "iş arkadaşları", "fiziksel ortam" ve "ücret ve personel" faktörlerinde ulaşılan p değeri <0,05 olmasından dolayı 
öğretmenlerin ve yöneticilerin yaşları açısından "yönetim biçimleri", "çalışma koşulları", "iş arkadaşları", "fiziksel ortam" ve "ücret ve personel" faktörlerinde iş doyumu düzeylerinde anlamlı bir farklılık olduğu sonucuna ulaşılmıştır. Analiz sonuçlarına göre "yönetim biçimleri", "çalışma koşulları", "iş arkadaşları", "fiziksel ortam" ve "ücret ve personel" faktörlerinde 44 ve üzeri yaş aralığında olan öğretmenlerin ve yöneticilerin diğer yaş gruplarına göre iş doyumu düzeylerinin daha yüksek olduğu belirlenmiştir (Tablo 5). $\mathrm{H}_{2 c}$ hipotezi desteklendi.

MEB'e bağlı ortaöğretim kurumlarında çalışan öğretmenlerin ve yöneticilerin eğitim düzeylerine göre iş doyumu düzeylerinde ve iş doyumunun tüm alt faktörlerinde bir farklılık olup olmadığını ölçmek için yapılan Kruskal Wallis $\mathrm{H}$ Testi analizi sonucunda, iş doyumu düzeyinde ve iş doyumunun tüm alt faktörlerinde ulaşılan $\mathrm{p}$ değeri $>0,05$ olmasından dolayı öğretmenlerin ve yöneticilerin eğitim düzeyleri açısından iş doyum düzeylerinde ve tüm alt boyutlarında anlamlı bir farklılık olmadığı sonucuna ulaşılmıştır (Tablo 6). $\mathrm{H}_{2 \mathrm{~d}}$ hipotezi reddedildi.

Tablo 5. Yaş Faktörü Açısından İş Doyumu Ölçek Ortalamaları

\begin{tabular}{|c|c|c|c|}
\hline & Yaş durumu & $\mathrm{N}$ & Ortalama \\
\hline \multirow[t]{6}{*}{ 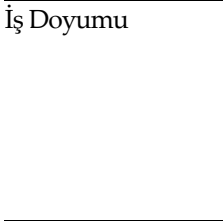 } & $20-25$ & 43 & 3,5676 \\
\hline & $26-31$ & 152 & 3,3158 \\
\hline & $32-37$ & 96 & 3,4450 \\
\hline & $38-43$ & 76 & 3,6040 \\
\hline & 44 ve üzeri & 34 & 3,8502 \\
\hline & Total & 401 & 3,4737 \\
\hline \multirow[t]{6}{*}{ Yönetim Biçimleri } & $20-25$ & 43 & 3,5907 \\
\hline & $26-31$ & 152 & 3,3829 \\
\hline & $32-37$ & 96 & 3,5635 \\
\hline & $38-43$ & 76 & 3,6737 \\
\hline & 44 ve üzeri & 34 & 3,9618 \\
\hline & Total & 401 & 3,5526 \\
\hline \multirow[t]{6}{*}{ Çalışma Olanakları } & $20-25$ & 43 & 2,7907 \\
\hline & $26-31$ & 152 & 2,5395 \\
\hline & $32-37$ & 96 & 2,7361 \\
\hline & $38-43$ & 76 & 3,1118 \\
\hline & 44 ve üzeri & 34 & 3,3382 \\
\hline & Total & 401 & 2,7897 \\
\hline \multirow[t]{5}{*}{ İş Arkadaşları } & $20-25$ & 43 & 3,8937 \\
\hline & $26-31$ & 152 & 3,7058 \\
\hline & $32-37$ & 96 & 3,6935 \\
\hline & $38-43$ & 76 & 3,8308 \\
\hline & 44 ve üzeri & 34 & 3,9580 \\
\hline
\end{tabular}




\begin{tabular}{|c|c|c|c|}
\hline & Total & 401 & 3,7681 \\
\hline \multirow[t]{6}{*}{ Fiziksel Ortam } & $20-25$ & 43 & 3,7209 \\
\hline & $26-31$ & 152 & 3,0461 \\
\hline & $32-37$ & 96 & 3,3750 \\
\hline & $38-43$ & 76 & 3,6645 \\
\hline & 44 ve üzeri & 34 & 3,8529 \\
\hline & Total & 401 & 3,3828 \\
\hline \multirow[t]{6}{*}{ Ücret ve Personel } & $20-25$ & 43 & 3,4302 \\
\hline & $26-31$ & 152 & 3,0987 \\
\hline & $32-37$ & 96 & 3,3125 \\
\hline & $38-43$ & 76 & 3,3158 \\
\hline & 44 ve üzeri & 34 & 3,9853 \\
\hline & Total & 401 & 3,3017 \\
\hline
\end{tabular}

Tablo 6. Öğretmenlerin ve Yöneticilerin Eğitim Düzeyleri Açısından İş Doyumu Düzeylerine Yönelik Kruskal Wallis-H Testi Sonuçlar

\begin{tabular}{|c|c|c|c|c|c|c|c|}
\hline & İş Doyumu & $\begin{array}{l}\text { Yönetim } \\
\text { Biçimleri }\end{array}$ & $\begin{array}{l}\text { Çalışma } \\
\text { Olanakları }\end{array}$ & $\begin{array}{l}\text { Gelişme } \\
\text { Yükselme } \\
\text { Olanakları }\end{array}$ & İş Ark. & $\begin{array}{l}\text { Fiziksel } \\
\text { Ortam }\end{array}$ & $\begin{array}{l}\text { Ücret ve } \\
\text { Personel }\end{array}$ \\
\hline Ki-kare & 3,729 & 3,855 & 6,663 & 459 & 1,872 & 890 & 1,087 \\
\hline$\overline{\mathrm{Df}}$ & 3 & 3 & 3 & 3 & 3 & 3 & 3 \\
\hline Asymp.Sig. & ,292 & 278 & ,083 & ,928 & ,599 & 828 & ,780 \\
\hline
\end{tabular}

Tablo 7. Öğretmenlerin ve Yöneticilerin Görevleri Açısından İş Doyumu Düzeylerine Yönelik Kruskal Wallis-H Testi Sonuçlarn

\begin{tabular}{|c|c|c|c|c|c|c|c|}
\hline & İş Doyumu & $\begin{array}{l}\text { Yönetim } \\
\text { Biçimleri }\end{array}$ & $\begin{array}{l}\text { Çalışma } \\
\text { Olanakları }\end{array}$ & $\begin{array}{l}\text { Gelişme } \\
\text { Yükselme } \\
\text { Olanakları }\end{array}$ & $\begin{array}{l}\text { ve } \\
\text { İş Ark. }\end{array}$ & $\begin{array}{l}\text { Fiziksel } \\
\text { Ortam }\end{array}$ & $\begin{array}{l}\text { Ücret ve } \\
\text { Personel }\end{array}$ \\
\hline Ki-kare & 24,722 & 22,561 & 12,350 & 5,453 & 14,025 & 11,961 & 20,426 \\
\hline Df & 2 & 2 & 2 & 2 & 2 & 2 & 2 \\
\hline \multicolumn{2}{|c|}{ Asymp.Sig. ,000 } &, 000 &, 002 &, 065 & ,001 & ,003 & ,000 \\
\hline
\end{tabular}

Katılımcların görev durumlarına göre iş doyumu düzeylerinde bir farklılık olup olmadığını ölçmek için yapılan Kruskal Wallis H Testi analizi sonucunda iş doyumu düzeyinde ulaşılan değer $p=0,000<0,05$ olmasından dolayı katılımcıların görevleri açısından iş doyum düzeylerinde anlamlı bir farklılık olduğu sonucuna ulaşılmıştır (Tablo 7). Analiz sonuçlarına göre iş doyumunda müdür olarak görev yapan katılımcların diğer görev gruplarına göre iş doyumu düzeylerinin daha yüksek olduğu belirlenmiştir. Alt faktörlerin tümüne yapılan analiz sonucunda "yönetim biçimleri", "çalışma koşulları", "iş arkadaşları", "fiziksel ortam" ve "ücret ve personel” faktörlerinde ulaşlan 
p değeri < 0,05 olmasından dolayı katılımcıların görevleri açısından "yönetim biçimleri", "çalışma koşulları", "iş arkadaşları", "fiziksel ortam" ve "ücret ve personel" faktörlerinde iş doyumu düzeylerinde anlamlı bir farklılık olduğu sonucuna ulaşılmıştır. Analiz sonuçlarına göre "yönetim biçimleri", "çalışma koşulları", "iş arkadaşları", "fiziksel ortam" ve "ücret ve personel" faktörlerinde müdür olarak görev yapan katılımcların diğer görev gruplarına göre iş doyumu düzeylerinin daha yüksek olduğu belirlenmiştir (Tablo 8). $\mathrm{H}_{2 \mathrm{e}}$ hipotezi desteklendi.

Tablo 8. Görev Faktörü Açısından İş Doyumu Ölçek Ortalamaları

\begin{tabular}{|c|c|c|c|}
\hline & Görevler & $\mathrm{N}$ & Ortalama \\
\hline \multirow[t]{4}{*}{ İş Doyumu } & Öğretmen & 382 & 3,4451 \\
\hline & Müdür Yardımcısı & 11 & 3,9688 \\
\hline & Müdür & 8 & 4,1563 \\
\hline & Total & 401 & 3,4737 \\
\hline \multirow[t]{4}{*}{ Yönetim Biçimleri } & Öğretmen & 382 & 3,5220 \\
\hline & Müdür Yardımcısı & 11 & 4,0273 \\
\hline & Müdür & 8 & 4,3625 \\
\hline & Total & 401 & 3,5526 \\
\hline \multirow{4}{*}{ Çalışma Olanakları } & Öğretmen & 382 & 2,7544 \\
\hline & Müdür Yardımcısı & 11 & 3,4242 \\
\hline & Müdür & 8 & 3,6042 \\
\hline & Total & 401 & 2,7897 \\
\hline \multirow[t]{4}{*}{ İş Arkadaşları } & Öğretmen & 382 & 3,7476 \\
\hline & Müdür Yardımcısı & 11 & 4,1558 \\
\hline & Müdür & 8 & 4,2143 \\
\hline & Total & 401 & 3,7681 \\
\hline \multirow[t]{4}{*}{ Fiziksel Ortam } & Öğretmen & 382 & 3,3429 \\
\hline & Müdür Yardımcısı & 11 & 4,0909 \\
\hline & Müdür & 8 & 4,3125 \\
\hline & Total & 401 & 3,3828 \\
\hline \multirow[t]{4}{*}{ Ücret ve Personel } & Öğretmen & 382 & 3,2579 \\
\hline & Müdür Yardımcısı & 11 & 4,0000 \\
\hline & Müdür & 8 & 4,4375 \\
\hline & Total & 401 & 3,3017 \\
\hline
\end{tabular}

Katılımcıların kıdemlerine göre iş doyumu düzeylerinde bir farklılık olup olmadığını ölçmek için yapılan Kruskal Wallis H Testi analizi sonucunda iş doyumu düzeyinde ulaşılan değer $p=0,000<0,05$ olmasından dolayı katılımcıların kıdemleri açısından iş doyum düzeylerinde anlamlı bir farklılık olduğu sonucuna ulaşılmıştır(Tablo 9). Analiz sonuçlarına göre iş doyumunda 
20 ve üzeri yıl kıdeme sahip katılımcıların diğger kıdem gruplarına göre iş doyumu düzeylerinin daha yüksek olduğu belirlenmiştir. Alt faktörlerin tümüne yapılan analiz sonucunda "yönetim biçimleri", "çalışma koşulları", "iş arkadaşları", "fiziksel ortam" ve "ücret ve personel" faktörlerinde ulaşılan p değeri < 0,05 olmasından dolayı katılımcıların kıdemleri açısından "yönetim biçimleri”, "çalışma koşulları", "iş arkadaşları", "fiziksel ortam” ve "ücret ve personel" faktörlerinde iş doyumu düzeylerinde anlamlı bir farklılık olduğu sonucuna ulaşılmıştır. Analiz sonuçlarına göre "yönetim biçimleri", "çalışma koşulları", "iş arkadaşları", "fiziksel ortam" ve "ücret ve personel” faktörlerinde 20 yıl ve üzeri kıdeme sahip katılımcıların diğer kıdem gruplarına göre iş doyumu düzeylerinin daha yüksek olduğu belirlenmiştir (Tablo 10). H2f hipotezi desteklendi.

Tablo 9. Öğretmenlerin ve Yöneticilerin Kıdemleri Açısından İş Doyumu Düzeylerine Yönelik Kruskal Wallis-H Testi Sonuçlan

\begin{tabular}{llllllll}
\hline & $\begin{array}{l}\text { İş } \\
\text { Doyumu }\end{array}$ & $\begin{array}{l}\text { Yönetim } \\
\text { Biçimleri }\end{array}$ & $\begin{array}{l}\text { Çalışma } \\
\text { Olanakları }\end{array}$ & $\begin{array}{l}\text { Gelişme ve } \\
\text { Yükselme Olanakları }\end{array}$ & $\begin{array}{l}\text { İş Ark. } \\
\text { Arks }\end{array}$ & $\begin{array}{l}\text { Fiziksel } \\
\text { Ortam }\end{array}$ & $\begin{array}{l}\text { Ücret ve } \\
\text { Personel }\end{array}$ \\
\hline Ki-kare & 23,997 & 19,387 & 36,906 & 1,430 & 13,147 & 14,666 & 15,691 \\
\hline Df & 4 & 4 & 4 & 4 & 4 & 4 & 4 \\
\hline Asymp. Sig., 000 &, 001 &, 000 &, 839 &, 011 &, 005 &, 003 \\
\hline
\end{tabular}

Öğretmenlerin ve Yöneticilerin Demografik Özellikleri Açısından Örgütsel Bağlılık Düzeylerinin tespitine yönelik kurulan hipotezler:

- $\mathrm{H}_{3}$ : Öğretmen ve yöneticilerin demografik faktörleri açısından örgütsel bağlılık düzeylerinde anlamlı bir farklılık vardır.

- $\mathrm{H}_{3 a}$ Öğretmen ve yöneticilerin cinsiyetleri açısından örgütsel bağlılık düzeylerinde anlamlı bir farklılık vardır.

- $\mathrm{H}_{3 b}$ : Öğretmen ve yöneticilerin medeni durumları açısından örgütsel bağlılık düzeylerinde anlamlı bir farklılık vardır.

- H3c: Öğretmen ve yöneticilerin yaşları açısından örgütsel bağlılık düzeylerinde anlamlı bir farklılık vardır.

- Hzd: Öğretmen ve yöneticilerin eğitim düzeyleri açısından örgütsel bağlılık düzeylerinde anlamlı bir farklılık vardır.

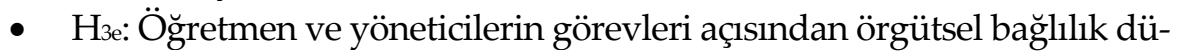
zeylerinde anlamlı bir farklılık vardır.

- Hзf: Öğretmen ve yöneticilerin kıdemleri açısından örgütsel bağlılık düzeylerinde anlamlı bir farklılık vardır. 
Ortaöğretim Kurumlarında Yönetici ve Öğretmenlerin İş Doyumunun Örgütsel Bağlılığa Etkisi: Şanlıurfa İlinde Bir Çalışma

Tablo 10. Kıdem Faktörü Açısından İş Doyumu Ölçek Ortalamaları

\begin{tabular}{|c|c|c|c|}
\hline & Kidem & $\mathrm{N}$ & Ortalama \\
\hline \multirow[t]{6}{*}{ İş Doyumu } & $1-5$ yil & 150 & 3,4138 \\
\hline & 6-10 yıl & 96 & 3,3473 \\
\hline & $11-15$ yil & 70 & 3,5058 \\
\hline & $16-20 \mathrm{yll}$ & 61 & 3,6194 \\
\hline & 20 ve üzeri & 24 & 3,8893 \\
\hline & Total & 401 & 3,4737 \\
\hline \multirow[t]{6}{*}{ Yönetim Biçimleri } & $1-5$ yil & 150 & 3,4787 \\
\hline & 6-10 yıl & 96 & 3,4313 \\
\hline & $11-15$ yll & 70 & 3,5814 \\
\hline & 16-20yıl & 61 & 3,7016 \\
\hline & 20 ve üzeri & 24 & 4,0375 \\
\hline & Total & 401 & 3,5526 \\
\hline \multirow[t]{6}{*}{ Çalışma Olanakları } & $1-5$ yil & 150 & 2,6267 \\
\hline & 6-10 yıl & 96 & 2,5538 \\
\hline & $11-15$ y1l & 70 & 2,8452 \\
\hline & $16-20 \mathrm{yll}$ & 61 & 3,2760 \\
\hline & 20 ve üzeri & 24 & 3,3542 \\
\hline & Total & 401 & 2,7897 \\
\hline \multirow[t]{6}{*}{ İş Arkadaşları } & $1-5$ yil & 150 & 3,7886 \\
\hline & 6-10 yıl & 96 & 3,6890 \\
\hline & $11-15$ yil & 70 & 3,7286 \\
\hline & $16-20 \mathrm{yll}$ & 61 & 3,7564 \\
\hline & 20 ve üzeri & 24 & 4,1012 \\
\hline & Total & 401 & 3,7681 \\
\hline \multirow[t]{6}{*}{ Fiziksel Ortam } & $1-5$ yil & 150 & 3,3067 \\
\hline & 6-10 yıl & 96 & 3,1146 \\
\hline & $11-15$ yll & 70 & 3,5357 \\
\hline & 16-20yıl & 61 & 3,6557 \\
\hline & 20 ve üzeri & 24 & 3,7917 \\
\hline & Total & 401 & 3,3828 \\
\hline \multirow[t]{6}{*}{ Ücret ve Personel } & $1-5$ yil & 150 & 3,2033 \\
\hline & 6-10 yıl & 96 & 3,2083 \\
\hline & $11-15$ y1l & 70 & 3,4714 \\
\hline & $16-20 \mathrm{yll}$ & 61 & 3,2295 \\
\hline & 20 ve üzeri & 24 & 3,9792 \\
\hline & Total & 401 & 3,3017 \\
\hline
\end{tabular}


Tablo 11. Öğretmenlerin ve Yöneticilerin Cinsiyetleri Açısından Örgütsel Bağhlık Düzeylerine Yönelik Mann Whitney U Testi Sonuçlan

\begin{tabular}{|c|c|c|c|c|}
\hline Örgütsel Bağlllık & $\mathrm{N}$ & Mean & Z & Sig. \\
\hline Kadın & 218 & 3,3020 & \multirow{2}{*}{$-2,120$} & \multirow{2}{*}{,034 } \\
\hline Erkek & 183 & 3,4189 & & \\
\hline Duygusal Bağlılık & $\mathrm{N}$ & Mean & $Z$ & Sig. \\
\hline Kadın & 218 & 3,4472 & \multirow{2}{*}{$-1,004$} & \multirow{2}{*}{,315 } \\
\hline Erkek & 183 & 3,5205 & & \\
\hline Devam Bağlılığ1 & $\mathrm{N}$ & Mean & $\mathrm{Z}$ & Sig. \\
\hline Kadın & 218 & 3,1737 & \multirow{2}{*}{$-2,562$} & \multirow{2}{*}{,010 } \\
\hline Erkek & 183 & 3,3579 & & \\
\hline Normatif Bağlılık & $\mathrm{N}$ & Mean & Z & Sig. \\
\hline Kadın & 218 & 3,2850 & \multirow{2}{*}{,- 700} & \multirow{2}{*}{484} \\
\hline Erkek & 183 & 3,3784 & & \\
\hline
\end{tabular}

Katılımcların cinsiyetlerine göre örgütsel bağlılık düzeylerinde bir farklılık olup olmadığını ölçmek için yapılan Mann Whitney U Testi analiz sonucunda ulaşılan değer $p=, 034<, 05$ olmasından dolayı öğretmenlerin ve yöneticilerin cinsiyetleri açısından örgütsel bağlllık düzeylerinde anlamlı bir farklılık olduğu sonucuna ulaşılmıştır. Katılımcıların cinsiyetlerine göre örgütsel bağllık ölçeğinin alt faktörlerinde de farklılık olup olmadığını belirlemek için her alt faktöre Mann Whitney U Testi yapılmıştır. Yapılan analiz sonucunda "Devam bağlılığı" faktöründen elde edilen p değeri ,010 <,05 olduğundan "Devam bağlllığı" faktöründe katılımcıların cinsiyetleri açısından örgütsel bağlılık düzeyinde anlamlı bir farklılık olduğu tespit edilmiştir (Tablo 11). $\mathrm{H}_{3 a}$ hipotezi desteklendi.

Tablo 12. Öğretmenlerin ve Yöneticilerin Medeni Durumlarn Açısından Örgütsel Bağhlık Düzeylerine Yönelik Mann Whitney U Testi Sonuçlarn

\begin{tabular}{|c|c|c|c|c|}
\hline Örgütsel Bağlılık & $\mathrm{N}$ & Mean & $Z$ & Sig. \\
\hline Evli & 129 & 3,3114 & \multirow{2}{*}{$-1,250$} & \multirow{2}{*}{ 211 } \\
\hline Bekar & 272 & 3,3762 & & \\
\hline Duygusal Bağlılık & $\mathrm{N}$ & Mean & $\mathrm{Z}$ & Sig. \\
\hline Evli & 129 & 3,4835 & \multirow{2}{*}{,- 082} & \multirow{2}{*}{,935 } \\
\hline Bekar & 272 & 3,4793 & & \\
\hline Devam Bağlılığ & $\mathrm{N}$ & Mean & $Z$ & Sig. \\
\hline Evli & 129 & 3,2432 & \multirow{2}{*}{,- 316} & \multirow{2}{*}{,752 } \\
\hline Bekar & 272 & 3,2647 & & \\
\hline Normatif Bağlılık & $\mathrm{N}$ & Mean & $\mathrm{Z}$ & Sig. \\
\hline Evli & 129 & 3,2074 & \multirow{2}{*}{$-1,856$} & \multirow{2}{*}{ 063 } \\
\hline Bekar & 272 & 3,3847 & & \\
\hline
\end{tabular}


Katılımciların medeni durumlarına göre örgütsel bağll1ık düzeylerinde bir farklılık olup olmadığını ölçmek için yapılan Mann Whitney U Testi analiz sonucunda ulaşılan değer $p=, 211>, 05$ olmasından dolayı katılımciların medeni durumları açısından örgütsel bağlılık düzeylerinde anlamlı bir farklılık olmadığı sonucuna ulaşılmıştır. Öğretmenlerin ve yöneticilerin medeni durumlarına göre örgütsel bağlllık ölçeğinin alt faktörlerinde de farklılık olup olmadığını belirlemek için Mann Whitney U Testi yapılmıştır. Yapılan analiz sonucunda alt faktörlerin tümünde elde edilen $p$ değeri $>, 05$ olmasından dolayı, tüm alt düzeyinde katılımcıların medeni durumları açısından örgütsel bağlılık düzeyinde anlamlı bir farklılık olmadığı tespit edilmiştir(Tablo 12). $\mathrm{H}_{3 \mathrm{~b}}$ hipotezi reddedildi.

Tablo 13. Öğretmenlerin ve Yöneticilerin Yaşlarn Açısından Örgütsel Bağlılık Düzeylerine Yönelik Kruskal Wallis-H Testi Sonuçlar

\begin{tabular}{lllll}
\hline & Örgütsel Bağlllık & Duygusal Bağlllık & Devam Bağlllı̆̆1 & Normatif Bağlllkk \\
\hline Ki-kare & 16,075 & 16,969 & 10,747 & 15,096 \\
\hline Df & 4 & 4 & 4 & 4 \\
\hline Asymp. Sig. &, 003 &, 002 &, 030 &, 005 \\
\hline
\end{tabular}

Tablo 14. Yaş Faktörü Açısından Örgütsel Bağlilık Ölçek Ortalamalarn

\begin{tabular}{|c|c|c|c|}
\hline & Yaş durumu & $\mathrm{N}$ & Ortalama \\
\hline \multirow[t]{6}{*}{ Örgütsel Bağlllık } & $20-25$ & 43 & 3,5213 \\
\hline & $26-31$ & 152 & 3,2648 \\
\hline & $32-37$ & 96 & 3,2895 \\
\hline & $38-43$ & 76 & 3,4178 \\
\hline & 44 ve üzeri & 34 & 3,5968 \\
\hline & Total & 401 & 3,3554 \\
\hline \multirow[t]{6}{*}{ Duygusal Bağlılık } & $20-25$ & 43 & 3,7151 \\
\hline & $26-31$ & 152 & 3,3840 \\
\hline & $32-37$ & 96 & 3,4128 \\
\hline & $38-43$ & 76 & 3,5411 \\
\hline & 44 ve üzeri & 34 & 3,6728 \\
\hline & Total & 401 & 3,4807 \\
\hline \multirow[t]{6}{*}{ Devam Bağlılığı } & $20-25$ & 43 & 3,4709 \\
\hline & $26-31$ & 152 & 3,1299 \\
\hline & $32-37$ & 96 & 3,2448 \\
\hline & $38-43$ & 76 & 3,2961 \\
\hline & 44 ve üzeri & 34 & 3,5110 \\
\hline & Total & 401 & 3,2578 \\
\hline \multirow[t]{6}{*}{ Normatif Bağlılık } & $20-25$ & 43 & 3,3779 \\
\hline & $26-31$ & 152 & 3,2804 \\
\hline & $32-37$ & 96 & 3,2109 \\
\hline & $38-43$ & 76 & 3,4161 \\
\hline & 44 ve üzeri & 34 & 3,6066 \\
\hline & Total & 401 & 3,3276 \\
\hline
\end{tabular}


Katılımcların yaş durumlarına göre örgütsel bağlllık düzeylerinde bir farklılık olup olmadığını ölçmek için yapılan Kruskal Wallis H Testi analizi sonucunda örgütsel bağlılık düzeyinde ulaşılan değer $p=0,003<0,05$ olmasından dolayı katılımcıların yaşları açısından örgütsel bağlılık düzeylerinde anlamlı bir farklılık olduğu sonucuna ulaşılmıştır (Tablo 13). Analiz sonuçlarına göre örgütsel bağlllıkta 44 ve üzeri yaş aralığında olan öğretmenlerin ve yöneticilerin diğer yaş gruplarına göre örgütsel bağlılık düzeylerinin daha yüksek olduğu belirlenmiştir. Alt faktörlerin tümüne yapılan analiz sonucunda "duygusal bağlılık", "devam bağlllığı", ve "normatif bağlılık" faktörlerinde ulaşılan p değerlerinin $<0,05$ olmasından dolayı katılımcıların yaşları açısından "“duygusal bağlılık", "devam bağlılı̆̆1", ve "normatif bağlllık" faktörlerinde örgütsel bağlılık düzeylerinde anlamlı bir farklılık olduğu sonucuna ulaşılmıştır. Analiz sonuçlarına göre "duygusal bağlllık", "devam bağlılığı", ve "normatif bağll11k" faktörlerinde 44 ve üzeri yaş aralığında olan öğretmenlerin ve yöneticilerin diğer yaş gruplarına göre örgütsel bağlllık düzeylerinin daha yüksek olduğu belirlenmiştir (Tablo 14). $\mathrm{H}_{3 c}$ hipotezi desteklendi.

Tablo 15. Öğretmenlerin ve Yöneticilerin Ĕ̆itim Düzeyleri Açısından Örgütsel Bă̆lılı Düzeylerine Yönelik Kruskal Wallis-H Testi Sonuçlarn

\begin{tabular}{lllll}
\hline & Örgütsel Bağllık & Duygusal Bağllık & Devam Bağllĭğı & Normatif Bağlllık \\
\hline Ki-kare & 2,564 & 6,030 & 2,071 & 1,867 \\
\hline Df & 3 & 3 & 3 & 3 \\
\hline Asymp. Sig. &, 464 &, 110 &, 558 &, 600 \\
\hline
\end{tabular}

Katılımcıların eğitim düzeylerine göre örgütsel bağlllık düzeylerinde ve bağlılığın tüm alt faktörlerinde bir farklılık olup olmadığını ölçmek için yapılan Kruskal Wallis H Testi analizi sonucunda, örgütsel bağlllık düzeyinde ve örgütsel bağllı̆ı̆ın tüm alt faktörlerinde ulaşılan p değeri $>0,05$ olmasından dolayı öğretmenlerin ve yöneticilerin eğitim düzeyleri açısından örgütsel bağlılık düzeylerinde ve tüm alt boyutlarında anlamlı bir farklılık olmadığı sonucuna ulaşılmıştır (Tablo 15). H3d hipotezi reddedildi.

Tablo 16. Öğretmenlerin ve Yöneticilerin Görevleri Açısından Örgütsel Bağhlık Düzeylerine Yönelik Kruskal Wallis-H Testi Sonuçları

\begin{tabular}{lllll}
\hline & Örgütsel Bağlllık & Duygusal Bağllık & Devam Bağlliğı & Normatif Băgllık \\
\hline Ki-kare & 25,404 & 17,308 & 23,319 & 22,095 \\
\hline Df & 2 & 2 & 2 & 2 \\
\hline Asymp. Sig. &, 000 &, 000 &, 000 &, 000 \\
\hline
\end{tabular}


Tablo 17. Görev Faktörü Açısından Örgütsel Bağhllık Ölçek Ortalamalarn

\begin{tabular}{|c|c|c|c|}
\hline & Görevler & $\mathrm{N}$ & Ortalama \\
\hline \multirow[t]{4}{*}{ Örgütsel Bağlllık } & Öğretmen & 382 & 3,3229 \\
\hline & Müdür Yardımcısı & 11 & 3,8561 \\
\hline & Müdür & 8 & 4,2188 \\
\hline & Total & 401 & 3,3554 \\
\hline \multirow[t]{4}{*}{ Duygusal Bağlllık } & Öğretmen & 382 & 3,4542 \\
\hline & Müdür Yardımcısı & 11 & 3,8068 \\
\hline & Müdür & 8 & 4,2969 \\
\hline & Total & 401 & 3,4807 \\
\hline \multirow[t]{4}{*}{$\overline{\text { Devam Bağlllığ1 }}$} & Öğretmen & 382 & 3,2179 \\
\hline & Müdür Yardımcısı & 11 & 3,8864 \\
\hline & Müdür & 8 & 4,2969 \\
\hline & Total & 401 & 3,2578 \\
\hline \multirow[t]{4}{*}{ Normatif Bağlılık } & Öğretmen & 382 & 3,2965 \\
\hline & Müdür Yardımcısı & 11 & 3,8750 \\
\hline & Müdür & 8 & 4,0625 \\
\hline & Total & 401 & 3,3276 \\
\hline
\end{tabular}

Katılımcıların görev durumlarına göre örgütsel bağlılık düzeylerinde bir farklılık olup olmadığını ölçmek için yapılan Kruskal Wallis H Testi analizi sonucunda örgütsel bağl1lık düzeyinde ulaşılan değer $p=0,000<0,05$ olmasından dolayı katılımcların görevleri açısından örgütsel bağlılık düzeylerinde anlamlı bir farklılık olduğu sonucuna ulaşılmıştır(Tablo 16). Analiz sonuçlarına göre örgütsel bağlllıkta müdür olarak görev yapan katılımciların diğer görev gruplarına göre örgütsel bağlllık düzeylerinin daha yüksek olduğu belirlenmiştir. Alt faktörlerin tümüne yapılan analiz sonucunda "duygusal bağlılık", "devam bağlılığı", ve "normatif bağlllık" faktörlerinde ulaşlan p değeri < 0,05 olmasından dolayı katılımciların görevleri açısından "duygusal bağlılık", "devam bağlılığı", ve "normatif bağlılık" faktörlerinde örgütsel bağllıı düzeylerinde anlamlı bir farklılık olduğu sonucuna ulaşılmıştır. Analiz sonuçlarına göre "duygusal bağlllık", "devam bağlllığı", ve "normatif bağlllık" faktörlerinde müdür olarak görev yapan katılımcıların diğer görev gruplarına göre örgütsel bağl1lık düzeylerinin daha yüksek olduğu belirlenmiştir (Tablo 17). H3e hipotezi desteklendi. 
Tablo 18. Öğretmenlerin ve Yöneticilerin Kıdemleri Açısından Örgütsel Bağhlık Düzeylerine Yönelik Kruskal Wallis-H Testi Sonuçlarn

\begin{tabular}{lllll}
\hline & Örgütsel Bağlllık & Duygusal Bağlllık & Devam Bağlllı̆̆ı & Normatif Bağlllı \\
\hline Ki-kare & 11,228 & 8,289 & 10,924 & 12,533 \\
\hline Df & 4 & 4 & 4 & 4 \\
\hline Asymp. Sig. &, 024 &, 082 &, 027 &, 014 \\
\hline
\end{tabular}

Tablo 19. Kıdem Faktörü Açısından Örgütsel Bağlılık Ölçek Ortalamaları

\begin{tabular}{|c|c|c|c|}
\hline & Kıdem & $\mathrm{N}$ & Ortalama \\
\hline \multirow[t]{6}{*}{ Örgütsel Bağllılı } & $1-5$ yil & 150 & 3,2642 \\
\hline & $6-10 \mathrm{yll}$ & 96 & 3,3980 \\
\hline & $11-15$ yll & 70 & 3,3369 \\
\hline & $16-20 \mathrm{yll}$ & 61 & 3,4488 \\
\hline & 20 ve üzeri & 24 & 3,5712 \\
\hline & Total & 401 & 3,3554 \\
\hline \multirow[t]{6}{*}{ Devam Bağllilı̆ 1} & $1-5 \mathrm{yll}$ & 150 & 3,1258 \\
\hline & 6-10 yil & 96 & 3,3333 \\
\hline & $11-15$ yll & 70 & 3,3446 \\
\hline & 16-20yıl & 61 & 3,2623 \\
\hline & 20 ve üzeri & 24 & 3,5156 \\
\hline & Total & 401 & 3,2578 \\
\hline \multirow[t]{6}{*}{ Normatif Bağlılık } & $1-5$ yil & 150 & 3,2108 \\
\hline & $6-10$ yl & 96 & 3,3997 \\
\hline & $11-15$ yıl & 70 & 3,2571 \\
\hline & $16-20 \mathrm{yll}$ & 61 & 3,4816 \\
\hline & 20 ve üzeri & 24 & 3,5833 \\
\hline & Total & 401 & 3,3276 \\
\hline
\end{tabular}

Katılımcların kıdemlerine göre örgütsel bağlılık düzeylerinde bir farklılık olup olmadığını ölçmek için yapılan Kruskal Wallis H Testi analizi sonucunda örgütsel bağl1lık düzeyinde ulaşılan değer $p=0,024<0,05$ olmasından dolayı katılımcıların kıdemleri açısından örgütsel bağlılık düzeylerinde anlamlı bir farklılık olduğu sonucuna ulaşılmıştır(Tablo 18). Analiz sonuçlarına göre örgütsel bağllıkta 20 ve üzeri yıl kıdeme sahip katılımcıların diğer k1dem gruplarına göre örgütsel bağlılık düzeylerinin daha yüksek olduğu belirlenmiştir. Alt faktörlerin tümüne yapılan analiz sonucunda "devam bağl1lığı", ve "normatif bağlılık" faktörlerinde ulaşılan p değeri $<0,05$ olmasından dolayı katılımcların kıdemleri açısından "devam bağlılığı", ve "normatif bağlılık" faktörlerinde örgütsel bağlllık düzeylerinde anlamlı bir farklılık olduğu sonucuna ulaşılmıştır. Analiz sonuçlarına göre "devam bağl1lığı", ve "normatif bağllık" faktörlerinde 20 yıl ve üzeri kıdeme sahip katılımcıların 
diğer kıdem gruplarına göre örgütsel bağlılık düzeylerinin daha yüksek olduğu belirlenmiştir(Tablo 19). H3f hipotezi desteklendi.

\section{Sonuçlar ve Değerlendirmeler}

İş doyumu düzeyi ile örgütsel bağlllık düzeyi arasındaki ilişkiyi belirlemeye yönelik olarak nonparametrik test olan Spearman Korelasyon Testi analizinde $\mathrm{p}$ değeri ,05 değerinden küçük olduğu için bu iki değişken arasında anlamlı bir ilişki olduğu tespit edilmiştir. İş doyumu düzeyi ve örgütsel bağlılık düzeyi arasındaki korelasyon kat sayısı değeri $\mathrm{r}=, 270$ olmasından dolayı aralarında pozitif ve zayıf bir ilişki olduğu sonucuna varılmıştır. Yani iş doyumu düzeyi arttıkça örgütsel bağlllık düzeyi de pozitif yönde artmaktadır. Elde edilen sonuç literatürdeki bazı çalışmalarla paralellik göstermektedir. Akınaltuğ' un (2003) yaptığı çalışmaya göre is doyumu yükseldikçe örgütsel bağlllı̆̆ın da yükseldiği görülmüştür. Durmaz (2003) ve Kaya (2005) yaptıkları birbirinden farklı araştırmalara göre is doyumunun alt boyutları ile örgütsel bağlılığın alt boyutları arasında anlamlı ilişki olduğunu göstermiştir. Bu araştırma sonuçları ile yukarıda belirtilen iki araştırmanın sonuçları örtüşmektedir.

Katılımcların cinsiyetlerine göre iş doyumu ölçeğinin alt faktörlerinde de farklılık olup olmadığını belirlemek için yapılan analiz sonucunda "Yönetim Biçimleri" ve "Çalışma Olanakları" faktörlerinde elde edilen p değerleri sırası ile ,032 ve ,004<,05 olduğundan bu iki faktör düzeyinde katılımcıların cinsiyetleri açısından anlamlı bir farklılık olduğu tespit edilmiştir. Her iki alt faktörde de erkeklerin kadınlardan daha yüksek doyum düzeyinde olduğu sonucuna ulaşılmıştır. Bu araştırmanın sonuçları ile literatürdeki bazı çalışmaların sonuçları arasında benzerlikler vardır. Akınaltuğ (2003), tarafından yapılan çalışmada cinsiyete göre is doyumu ile arasında anlamlı fark bulunduğunu ortaya koymuş ve kadın çalışanların erkeklere nazaran is doyumlarının daha zayıf olduğunu söylemiştir. Kaya (2005), tarafından yapılan çalışmada iş doyumunun çalışma şartları alt boyutunda cinsiyete bağlı anlamlı fark bulunmaktadır. Kadın çalışanların iş doyum düzelerinin erkek çalışanlara göre daha düşük olduğu belirtilmiştir. Bu çalışmaların bulguları bu çalışmanın bulguları ile örtüşmektedir

Analiz sonucunda ulaşılan medeni durum için $p=, 176>, 05$ olmasından dolayı öğretmenlerin ve yöneticilerin medeni durumları açısından iş doyumu 
düzeylerinde anlamlı bir farklılık olmadığı sonucuna ulaşılmıştır. Öğretmenlerin ve yöneticilerin medeni durumlarına göre iş doyumu ölçeğinin "Çalışma Olanakları", "Fiziksel Ortam" ve "Ücret ve Personel” alt faktörlerinde elde edilen p değerleri sirası ile ,008, 040 ve ,009<,05 olduğundan bu üç faktör düzeyinde katılımcıların medeni durumları açısından anlamlı bir farklılık olduğu tespit edilmiştir. Her üç alt faktörde de bekarların evlilerden daha yüksek doyum düzeyinde olduğu sonucuna ulaşılmıştır.

Katılımcların yaş, eğitim düzeyine, görev durumları ve kıdemlerine göre iş doyumu düzeylerinde $\mathrm{p}=0,000<0,05$ olmasından dolayı öğretmenlerin ve yöneticilerin yaşları açısından iş doyum düzeylerinde anlamlı bir farklılık olduğu sonucuna ulaşılmıştır. Analiz sonuçlarına göre "yönetim biçimleri", "çalışma koşulları", "iş arkadaşları", "fiziksel ortam" ve "ücret ve personel" faktörlerinde 44 ve üzeri yaş aralığında olan öğretmenlerin ve yöneticilerin diğer yaş gruplarına göre iş doyumu düzeylerinin daha yüksek olduğu belirlenmiştir. Elde edilen sonuçlar literatürdeki bazı çalışmalardan elde edilen sonuçlarla örtüşmektedir. Akınaltuğ (2003) yaptığı incelemelerde 20-40 yaş ile 41 yas ve üstü iş görenlerde yöneticilerin iş doyumları arasında anlamlı fark görülmemiştir. Ancak 20-40 yaş arası iş görenlerde iş doyumu daha zayıf görülmüştür. MEB yöneticilerinin iş doyumlarının yaşa bağlı anlamlı farklılık algılanmamasının yanında iş doyum düzeyinin en fazla 60 yaş üstü, en zayıf iş doyumunun ise 30 yaş altı iş görenlerde olduğu tespit edilmiştir. Çetinkanat'ın (1988) yaptığı çalışmaya göre öğretmenlerin iş doyumlarının yaşa yönelik anlamlı ilişkisinin tespiti için yaptığı tek yönlü varyans analizine göre iş doyumunun "saygınlik", "otonomi", ve "kendini gerçekleştirme" alt unsurlarında anlamlı ilişki görülmüştür. Araştırmaya göre 20- 34 yaş arası öğretmenlerde "saygınlık" yönünden doyumun en zayıf olduğu, 45-54 yaş arası öğretmenlerin sayginlık yönünden doyum düzeyinin en yüksek olduğu saptanmiştır.

Katılımcların görev durumlarına göre iş doyumu düzeylerinde $\mathrm{p}=0,000<0,05$ olmasından dolayı katılımcıların görevleri açısından iş doyum düzeylerinde anlamlı bir farklılık olduğu sonucuna ulaşılmıştır. Analiz sonuçlarına göre iş doyumunda müdür olarak görev yapan katılımcların diğer görev gruplarına göre iş doyumu düzeylerinin daha yüksek olduğu belirlenmiştir. Analiz sonuçlarına göre "yönetim biçimleri", "çalışma koşulları", "iş arkadaşları", "fiziksel ortam" ve "ücret ve personel" faktörlerinde müdür 
olarak görev yapan katılımcların diğer görev gruplarına göre iş doyumu düzeylerinin daha yüksek olduğu belirlenmiştir. Kaya (2005) tarafından yapılan araştırmada iş statülerine yönelik çalışanların iş doyumunun düzeyleri ile fiziksel ortam ve iş arkadaşları haricindeki bütün alt boyutlarda anlamlı bir farklılık tespit edilmiş. İş statülerindeki ilerleme ye bağlı olarak iş doyumunun da yükseldiği belirtilmiştir. Bu çalışmanın sonuçlarıyla paralellik göstermektedir. Çetinkanat' in (2008) yaptığ 1 çalışmaya göre öğretim elemanlarının iş doyumuna yönelik görev statüleri arasındaki ilişki düzeyinin 0.05 olarak anlamlı bir fark gözlenmemiştir. Çetinkanat'ın araştırmasının sonuçları bu çalışmanın sonuçlarını desteklememektedir.

Katılımcların kıdemlerine göre iş doyumu düzeylerinde $p=0,000<0,05$ olmasından dolayı katılımcıların kıdemleri açısından iş doyum düzeylerinde anlamlı bir farklılık olduğu sonucuna ulaşılmıştır. Analiz sonuçlarına göre iş doyumunda 20 ve üzeri yıl kıdeme sahip katılımcıların diğer kıdem gruplarına göre iş doyumu düzeylerinin daha yüksek olduğu belirlenmiştir. Analiz sonuçlarına göre "yönetim biçimleri", "çalışma koşulları", "iş arkadaşları", "fiziksel ortam" ve "ücret ve personel" alt faktörlerinde 20 yıl ve üzeri k1deme sahip katılımcıların diğer kıdem gruplarına göre iş doyumu düzeylerinin daha yüksek olduğu belirlenmiştir. Serengil'in (1997) yaptığı çalışmaya göre, çalışanların çalışma kıdemleri ile iş doyumu çoğunlukla anlamlı farklılaşma görülmemiştir. Bu çalışmanın sonuçlarıyla farklılıklar göstermektedir.

Katılımcıların cinsiyetlerine göre örgütsel bağlllık düzeylerinde $\mathrm{p}=, 034<, 05$ olmasından dolayı öğretmenlerin ve yöneticilerin cinsiyetleri aç1sindan örgütsel bağlılık düzeylerinde anlamlı bir farklılık olduğu sonucuna ulaşılmıştır. Yapılan analiz sonucunda "Devam bağlılığı" faktöründen elde edilen p değeri ,010 <,05 olduğundan “Devam bağlılığ1" faktöründe katılımcıların cinsiyetleri açısından örgütsel bağlılık düzeyinde anlamlı bir farklılık olduğu tespit edilmiştir. İrban (2004), tarafından yapılan araştırmada çalışanların özdeşleşme, uyum ve içselleştirme alt unsurlarında örgütsel bağll1ık düzeyleri arasında anlamlı bir fark görülmüştür. Özdeşleşme ve içselleştirme alt boyutlarında kadın çalışanların erkek çalışanlarının örgütsel bağllılk düzeylerinin daha düşük olduğu, ancak uyum alt boyutunda erkek çalışanların kadın çalışanlara göre örgütsel bağlılıkları daha zayıf olduğu belirtilmiştir. Kısmen de olsa bu çalışmanın sonuçlarını desteklemektedir. Erdoğan (2004), tarafından yapılan araştırmaya göre ilköğretim okullarında çalışan yöneticilerin örgütsel bağlılıklarının cinsiyette bağlı düzeylerine bakıldığında kadın 
yöneticilerinin erkek yöneticilerden daha yüksek bir bağlılık duyduğu saptanmıştır. Ancak cinsiyetin devam ve normatif bağll1ık düzeylerinde bir farklilık görülmemiştir.

Katılımclların yaş durumlarına göre örgütsel bağlllık düzeylerinde $\mathrm{p}=0,003<0,05$ olmasından dolayı katılımcıların yaşları açısından örgütsel bağlllık düzeylerinde anlamlı bir farklılık olduğu sonucuna ulaşılmıştır. Analiz sonuçlarına göre örgütsel bağllılıta 44 ve üzeri yaş aralığında olan öğretmenlerin ve yöneticilerin diğer yaş gruplarına göre örgütsel bağlılık düzeylerinin daha yüksek olduğu belirlenmiştir. Analiz sonuçlarına göre "duygusal bağlllık", "devam bağlllığı", ve "normatif bağlllık" alt faktörlerinde 44 ve üzeri yaş aralığında olan öğretmenlerin ve yöneticilerin diğer yaş gruplarına göre örgütsel bağlllık düzeylerinin daha yüksek olduğu belirlenmiştir. Tok (2004), tarafından yapılan araştırmaya göre ilköğretim müfettişlerinin örgütsel bağlılıklarının çalışıldığı, 51-60 yaşlarındaki iş görenlerin örgütsel bağlılık düzeylerinin daha fazla olduğu saptanmıştır. Bu çalışmanın sonuçlarıyla paralellik göstermiştir. Akınaltuğ'ın (2003) yaptığı araştırmada yöneticilerin yaş düzeylerinin örgütsel bağlllık seviyeleri ile ilgili anlamlı bir fark görülmemiştir.

Katılımcıların görev durumlarına göre örgütsel bağlllık düzeylerinde $\mathrm{p}=0,000<0,05$ olmasından dolayı katılımcıların görevleri açısından örgütsel bağlılık düzeylerinde anlamlı bir farklılık olduğu sonucuna ulaşılmıştır. Analiz sonuçlarına göre örgütsel bağlılıkta müdür olarak görev yapan katılımc1ların diğer görev gruplarına göre örgütsel bağlllık düzeylerinin daha yüksek olduğu belirlenmiştir. Analiz sonuçlarına göre "duygusal bağlılık", "devam bağlılığı", ve "normatif bağlılık" alt faktörlerinde müdür olarak görev yapan katılımcıların diğer görev gruplarına göre örgütsel bağlılık düzeylerinin daha yüksek olduğu belirlenmiştir. Akınaltuğ'un (2003), yaptığı araştırmada çalışanların yöneticilik görevleriyle örgütsel bağlılık düzeyleri arasında anlamlı bir farklılaşma saptanmamıştır. Çalışmada yöneticilik görevleri statüsü artıkça örgütsel bağlllık seviyesi bir miktar artığı görülmüştür. Araştırma sonuçları ile bu çalışmanın sonuçları bir birbiriyle örtüşmektedir. Kaya (2005), tarafından yapılan araştırmaya göre uyum, özdeşleşme ve içselleştirme alt boyutlarında yükselme görüldükçe örgütsel bağlllık düzeyinin de yükseleceği görülmüştür. Araştırma sonuçları ile bu çalışmanın sonuçları bir birbiriyle örtüşmektedir. 
Katılımcların kıdemlerine göre örgütsel bağlllık düzeylerinde $p=0,024<0,05$ olmasından dolayı katılımcların kıdemleri açısından örgütsel bağllık düzeylerinde anlamlı bir farklılık olduğu sonucuna ulaşılmıştır. Analiz sonuçlarına göre "devam bağl1lı̆gı", ve "normatif bağl1lık" alt faktörlerinde 20 yıl ve üzeri kıdeme sahip katılımcıların diğer kıdem gruplarına göre örgütsel bağlılık düzeylerinin daha yüksek olduğu belirlenmiştir. Erdoğan'ın (2004) yaptığı çalışmada; ilköğretim okullarında çalışan yönetici ve öğretmenlerin, kıdemlerine bağlı olarak duygusal ve devam bağlılık seviyeleri arasinda anlamlı bir farklılığın görülmediği ancak normatif bağlılık seviyeleri arasında 21 yıl ve üzeri kıdemi olan iş görenlerin 1-5 yıl kıdemi olanlara nazaran normatif bağllıklarının düzeylerinin daha iyi çıtığı görülmüştür. $\mathrm{Bu}$ çalışmanın sonuçları ile paralellik göstermektedir.

Araştırma iş doyumu ve örgütsel bağlllık ilişkisinin daha görünür olduğu düşünülen eğitim sektöründe yapılmıştır. Zaman ve bütçe darlığı açısından araştırma Şanlıurfa ilinde gönüllü katılımlı olarak yapılmıştır. Bundan sonraki çalışmaların daha büyük bir ana kütle üzerinde, farklı sektörlerde ve farklı illerde yapılması sonuçların genelleştirilmesi için daha faydalı olacaktır.

Öneriler: Araştırma amacı doğrultusunda oluşturulan anketin Şanlıurfa ilinde orta öğretim kurumlarında çalışan yöneticilere ve öğretmenlere uygulanması sonucunda elde edilen verilerin analizi sonuçlarına göre geliştirilen öneriler aşağıda yer almaktadır.

- Ortaöğretim kurumlarında görev yapan yönetici ve öğretmenlerin iş doyum düzeylerinin çeşitli faaliyetlerle ve iş ortamı koşullarının iyileştirilmesiyle yüksek tutulmasına dikkat edilmelidir.

- Kadın çalışanların iş doyum ve örgütsel bağlılıklarını artırmak için önlemler alınmalıdır.

- Personellerin çoğunun evli olmaları göz önüne alındığında bu kadar büyük bir kitlenin iş doyumu ve örgütsel bağlllık düzeylerini artırmak için önlemler alınmalıdır.

- Ortaöğretimde çalışan yönetici ve öğretmenlerin çoğunluğunun 44 yaş ve altı olduğu düşünüldüğünde iş doyum ve örgütsel bağlılıklarının artırmak için önlemler alınması büyük önem arz etmektedir.

- $\quad 1$ - 5 yıl kıdemi olan öğretmenlerin iş doyumu ve örgütsel bağlılıklarını artırmak için gerekli çalışmalarla önlemler alınmalıdır. 
Bu çalışmada edinilen analiz sonuçlarına göre yönetici ve öğretmenlerin iş doyumları artıkça örgütsel bağlılıklarının da artığı görülmüştür. Bundan dolayı kurumların iş doyumları düşük olan gruplar için gerekli şartları sağlayarak, hizmet içi çalışmalar yaparak iş doyum düzeylerini ve dolaylı olarak da çalıştıkları kurumlarına bağlılıklarını artırma yollarına gitmelidir. 


\title{
EXTENDED ABSTRACT
}

\section{Ortaöğretim Kurumlarında Yönetici ve Öğretmenlerin İş Doyumunun Örgütsel Bağlılığa Etkisi: Şanlıurfa İlinde Bir Çalışma}

\author{
Hüseyin Yıldız - Kasım Kaya \\ Harran University
}

This research is aimed at determining the level of affecting the job satisfaction of administrators and teachers working in secondary education institutions affiliated to the Ministry of National Education on their organizational commitment. In addition, whether there are significant differences between these levels in terms of demographic factors is another research subject. The main body of the study consists of teachers and administrators working in secondary education institutions in the province of Şanlıurfa. Of all non-random sampling methods, the sample of the research is convenience sampling. The universe of the study consists of 6182 people. The sample size was determined as 357 with 95\% reliability and 5\% margin of error (Yazıcıoğlu \& Erdoğan, 2004, p.50). The questionnaire was filled out by 401 teachers and administrators. The data required for the research were collected by using face-toface survey method, one of the primary data collection methods. Face-to-face survey method, in which the surveyor communicates with the respondent, is among the most reliable data collection methods (Gegez, 2010, p. 83).

The questionnaire form consists of three parts. In the first part, six demographic questions, including gender, age, marital status, education level, position and seniority, are included. In the second part, there is a job satisfaction scale consisting of 32 items developed by Çetinkanat (2000). In the third part, there is an organizational commitment scale consisting of 24 items developed by Meyer and Allen (1997).

The data collected through the research were analysed using the SPSS program. Shapiro-Wilk Test was used to determine the normal distribution of the data. In the study, Mann Whitney U Test and Kruskal Wallis-H Test were used to investigate differences in the context of factor analysis, frequency analysis and demographic factors. In addition, Spearman Correlation 
Test was used to determine the relationship between job satisfaction and organizational commitment. Cronbach's Alpha values were calculated to measure the reliability of the scales.

In the Spearman Correlation Test analysis, which is a nonparametric test to determine the relationship between job satisfaction level and organizational commitment, a significant relationship was found between these two variables, since the $\mathrm{p}$ value was less than 05 . Since the correlation coefficient value between job satisfaction level and organizational commitment level is $\mathrm{r}=$ 270 , it is concluded that there is a positive and weak relationship between them. In other words, as job satisfaction enhances, organizational commitment increases positively.

As a result of the analysis made to determine whether there is a difference in the sub-factors of the job satisfaction scale according to the gender of the participants, the $p$ values obtained in the "Management Styles" and "Working Opportunities" factors are respectively, 032 and $.004<.05$, and so, it was determined that there is a significant difference in terms of the gender of the participants at these two factor levels. It was concluded that males were at a higher level of satisfaction than females in both sub-factors.

The analysis determined $p=, 176>, 05$ for the marital status and for this reason, it was concluded that there was no significant difference in job satisfaction levels in terms of the marital status of teachers and administrators. According to the marital status of teachers and administrators, the $\mathrm{p}$ values obtained in the "Work Opportunities", "Physical Environment" and "Wages and Personnel" sub-factors of the job satisfaction scale are respectively 008, 040 and, $009<.05$. and for this reason, it was determined that there is a significant difference in terms of the marital status of the participants at these three factor levels. In all three sub-factors, it was concluded that singles had a higher level of satisfaction than married people.

It has been concluded that there is a significant difference in the job satisfaction levels of teachers and administrators in terms of age, due to $p=0.000$ $<0.05$ in the job satisfaction levels of the participants according to their age, education level, task status and seniority. According to the analysis results, it was determined that teachers and administrators aged 44 and above have higher job satisfaction levels than other age groups in the factors of "management styles", "working conditions", "colleagues", "physical environment" and "wages and personnel". 
Due to $p=0.000<0.05$ in the job satisfaction levels of the participants according to their task status, it has been concluded that there is a significant difference in the job satisfaction levels of the participants in terms of their tasks. According to the analysis results, it was determined that the job satisfaction level of the participants who worked as managers in job satisfaction was higher than the other task groups.

As a result of $p=0.000<0.05$ in the job satisfaction level of the participants according to their seniority, it was concluded that there was a significant difference in the job satisfaction levels of the participants in terms of their seniority. According to the results of the analysis, it was determined that the job satisfaction level of the participants with 20 or more years of seniority was higher than the other seniority groups.

It has been concluded that there is a significant difference in the organizational commitment levels of teachers and administrators in terms of their gender, since the organizational commitment levels of the participants are $\mathrm{p}=$, $034<05$ according to their gender. As a result of the analysis, the $\mathrm{p}$ value obtained from the "attendance commitment" factor was $010<.05$, so it was found that there was a significant difference in the level of organizational commitment in terms of the gender of the participants in the "attendance commitment" factor.

It was concluded that there was a significant difference in the organizational commitment levels of the participants in terms of their ages, as a consequence of $p=0.003<0.05$ in the organizational commitment levels of the participants according to their age. According to the results of the analysis, it was determined that teachers and administrators in the age range of 44 and over in organizational commitment have higher levels of organizational commitment than other age groups.

Due to $p=0.000<0.05$ in the organizational commitment level of the participants according to their task status, it was concluded that there was a significant difference in the organizational commitment levels of the participants in terms of their duties. According to the results of the analysis, it was determined that the organizational commitment levels of the participants working as managers in organizational commitment were higher than other task groups.

As a result of $p=0.024<0.05$ in the organizational commitment levels of the participants according to their seniority, it was concluded that there was 
a significant difference in the organizational commitment levels of the participants in terms of their seniority. According to the results of the analysis, it was determined that the organizational commitment levels of the participants with a seniority of 20 years or more were higher in the sub-factors of "attendance commitment" and "normative commitment" compared to other seniority groups.

According to the results of the analysis obtained in this study, it was seen that as the job satisfaction of the administrators and teachers enhanced, their organizational commitment increased. For this reason, institutions should seek to increase their job satisfaction level and indirectly their loyalty to their institutions by providing the necessary conditions for groups with low job satisfaction, by doing in-service activities.

\section{Kaynakça / References}

Akınaltuğ, E. (2003). Yöneticilerde iş stresi, iş doyumu ve örgütsel bağhllhk analizi: Tedaş Örneği. Yayımlanmamış Yüksek Lisans Tezi, Kırıkkale Üniversitesi, Kırıkkale

Alan, H. (2010). Bilgi iş̧̧̧lerinin iş tatmininin örgütsel bağhllk üzerindeki etkileri ve bir kamu kurumunda çalş̧an bilgi iş̧̧ileri üzerindeki uygulama. Yayımlanmamış Yüksek Lisans Tezi, Gazi Üniversitesi. Ankara

Altunışık, R., Coşkun, R., Bayraktaroğlu, S., ve Yıldırım, E. (2005). Sosyal bilimlerde araştırma yöntemleri, SPSS uygulamal. Sakarya: Sakarya Kitabevi.

Çetinkanat, A. C. (2000). Örgütlerde güdülenme ve iş doyumu. Ankara: Anı Yayıncilık

Ergü, A. (1998). Milli Eğitim Müfettişlerinin iş doyumu. (Yayımlanmamış Yüksek Lisans Tezi), Ankara Üniversitesi. Ankara

Gegez, A. E. (2010). Pazarlama araştırmaları. Geliştirilmiş Üçüncü Bask. İstanbul: Beta Yayınlari

Karaca, S. (2001). İş tatmininin örgütsel bağlllk üzerindeki etkisi ve bir uygulama. (Yayımlanmamış Yüksek Lisans Tezi), Pamukkale Üniversitesi. Denizli

Kaya, F. T. (2005). İ̧ doyumu ve örgütsel bağlllk: Polis Akademisi Başkanlı̆̆ıda bir uygulama. (Yayımlanmamış Yüksek Lisans Tezi), Gazi Üniversitesi. Ankara

Luthans, F. (1992). Organizational behavior, McGraw- Hill International editions. New York. Singapore: Management Series.

Mahmutoğlu, A. (2007). Milli Ĕ̆itim Merkezörgütünde iş doyumu ve örgütsel bağlllk. (Yayınlanmış Doktora Tezi), Abant İzzet Baysal Üniversitesi, Bolu

Mavuş, N. (2014). Milli Ë̆̈itim Bakanlğ̆ merkez teşkilatı çalş̧anlarmmn iş doyumlarnm örgütsel bağhlh̆̆g etkileri hakkndaki görüşleri. (Yayımlanmamış Yüksek Lisans Tezi), Gazi Üniversitesi, Ankara 
Meyer, J.P and N.J Allen, (1997). Commitment in the workplace, theory, research and application, ATOB, Sage Publications. USA: International Educational and Professional Publisher.

Mowday, R.T, L.W Porter, and R.M Steers, (1992). The measurement of organizational commitment. Journal of Vocational Behavior, 14,1979. New York" aktaran Luthans Fred, Organizational Behavior, McGraw- Hill International Editions, Management Series. Singapore

Peterson, D., Puia, K., Georgia M. and Suess, F. R. (2003). An exploration of job satisfaction and commitment among workers in Mexico. Journal of Liedership and Organizational Studies, 10(2), 73-88

Proctor, T. (2003). Pazarlama araştırmasımın temelleri. İclem Er (Çeviren). İstanbul: Bilim Teknik Yayınevi.

Sipahi, B., Yurtkolu, E. S. ve Çinko, M. (2006). Sosyal bilimlerde SPSS'le veri analizi. İstanbul: Beta Yayınları

Şenergüç, S. (2009). Örrütsel bağhlhğın iş doyumu üzerindeki etkileri ve özel sektörde bir uygulama. Yayımlanmamış Yüksek Lisans Tezi, Dokuz Eylül Üniversitesi. İzmir

Tok, T. (2007). Ilköŏgretim müfettişlerinin iş doyumu ve örgütsel bağhllkkları. Ankara TemSen Yayınları.

Tok, T. N. (2004). İlköğretim müfettişlerinin iş doyumu ve örgütsel bağhllkları. (Yayınlanmamış Doktora Tezi), Ankara Üniversitesi, Ankara

Yazıcıoğlu, Y. ve Erdoğan, S. (2004). Spss uygulamalı bilimsel araştırma yöntemleri. Ankara: Detay Yayıncilik.

Yıldız, B. (2013). İlkokul ve ortaokul öğretmenlerinin iş stresi, örgütsel bağhllk ve iş doyumuna yönelik alglarmmn incelenmesi. (Yayımlanmamış Yüksek Lisans Tezi), Maltepe Üniversitesi. İstanbul

Yılmaz, A. ve Ceylan, Ç. B. (2011). İköğretim okul yöneticilerinin liderlik davranış düzeyleri ile ilköğretim öğretmenlerin iş doyumu ilişkisi. Kuram ve Uygulamada Eğitim Yönetimi, 17(2), 277-394.

Ylldırım, F. (2002). Çalışma yaşamında örgüte bağhlık ve örgütsel adalet ilişkisi. (Yayımlanmamış Doktora Tezi), Ankara Üniversitesi, Ankara

\section{Kaynakça Bilgisi / Citation Information}

Kaya, K. ve Yıldız, H. (2020). Ortaöğretim kurumlarında yönetici ve öğretmenlerin iş doyumunun örgütsel bağlllığa etkisi: Şanlıurfa ilinde bir çalışma. OPUS-Uluslararası Toplum Araştırmaları Dergisi, 16(31), 4317-4349. DOI: 10.26466/opus.692816 